\title{
The hydrocarbon compounds sources in surface sediments of the Laptev Sea shelf
}

\author{
I.A. Oberemok, E.V. Gershelis \\ Division for Geology, School of Earth Sciences \& Engineering, Tomsk Polytechnic University, \\ Tomsk, Russia
}

\begin{abstract}
Rapid warming of the Arctic provokes large-scale degradation of permafrost on land terrestrial and in submarines. A vast amount of remobilized organic matter $(\mathrm{OM})$ is involved in the modern biogeochemical cycle. Understanding of the fate of terrestrial OM moving from the land to the Arctic shelf is essential for predicting the potential feedback of Arctic ecosystems. In our research, an attempt was made to characterize the modern OM stored in the surface sediments of the Laptev Sea to estimate its composition variability and to identify the OM sources along with the "coastline - outer shelf" profile. Here we discuss the OM features revealed by Rock-Eval pyrolysis (RE) and the distribution of $n$ alkanes in combination with sediment grain-size analysis. The GC/MS records are directly comparable with $\mathrm{RE}$ data tracing the terrestrial $\mathrm{OM}$ along with the entire studied profile. However, we observe both a significant decline of terrestrial input and the rise of hydrobiont in the outer shelf zone. We assume that different OM sources may produce different ranges of RE values.
\end{abstract}

\section{Introduction}

Increasing global warming in the Arctic leads to a significant rate of terrestrial and submarine permafrost degradation $[1,2]$. The thermal state of the permafrost reaches the critical destabilization point, which, in its turn, triggers the remobilization of the huge amounts of previously frozen organic carbon (OC) and its involvement in the modern biogeochemical cycle. Moreover, the Arctic ecosystem has a low regenerative capacity or resilience due to the prevailing year-round negative temperature and scarce biota, which aren't capable to reduce the stress connected with climate change $[3,4]$. It was shown that an increased supply of remobilized ("old") OC may lead to severe acidification [5] of the Arctic waters and significantly contribute to the greenhouse effect as a result of the OC to $\mathrm{CO} 2$ transformation [6]. According to preliminary estimates, about $44 \pm 10 \mathrm{Mt}$ [7] of terrestrial OC is exported to the East Siberian Arctic shelf by coastal erosion only. Reliable identification of both OM sources and the mechanisms of its transformation within the "land - shelf" system is an important step towards a comprehensive understanding of the modern Arctic carbon cycle. We can observe that the most vulnerable region is the most severe recipient of climate change, and this situation requires a detailed complex study.

In recent years, OM stored in the surface sediments of the Arctic seas has been a subject of growing interest, and many complex studies performed with molecular and isotopic tools 
have been published [8-12]. In this work, we use a special, adapted Rock-Eval (RE) pyrolysis program to get new insights into the OM composition of surface sediments across the vast area of the Laptev Sea shelf. RE data for the East Siberian Arctic shelf are extremely limited. The Rock-Eval pyrolytic analysis is a traditional method in petroleum geology used to assess the oil generation potential of sedimentary rocks. Nevertheless, at present, the Rock-Eval method is increasingly used to study the organic components of soils and modern sediments. It was shown that pyrolytic analysis of immature organic material can provide valuable information about the sedimentary OM genesis and the degree of its diagenetic transformation. The Rock-Eval pyrolysis can serve as an additional tool that effectively complements the traditional geochemical methods for elemental, molecular, and isotopic composition identification.

\section{Materials and methods}

\subsection{Study Area}

The East Siberian Arctic Shelf (ESAS), represented by the Laptev Sea, the East Siberian Sea, and the Russian part of the Chukchi Sea, is unique because it occupies a huge area $\left(>2 * 10^{6} \mathrm{~km}^{2}\right)$ and has a shallow average depth $(\sim 50 \mathrm{~m})$. Moreover, the ESAS contains more than $80 \%$ of the world's subsea permafrost which is believed to store permafrost-related and continental slope methane hydrates [13-15].

This research focuses on the transect of the Laptev Sea, the shallowest sea in the Arctic. More than half of the seabed (53\%) is occupied by a slightly sloping shallow continental shelf with depths of up to $50 \mathrm{~m}$. Up to $76^{\circ} \mathrm{N}_{2}$ the depth does not exceed $25 \mathrm{~m}$. In the northern part, the bottom drops abruptly to the ocean floor with depths of $\sim 1 \mathrm{~km}(22 \%$ of the sea area).

The Laptev Sea is an Arctic sea dominated by terrestrial OMthat receives a substantial contribution from both coastal erosion and Lena river runoff [16,17]. It was previously shown that accelerating coastal erosion acts as the main contributor to the terrestrial $\mathrm{OM}$ pool exported to the Laptev Sea [7]. About 25\% of the Laptev Sea coastline is composed of ice-rich permafrost deposit [1] known as the Yedoma Ice Complex which is highly susceptible to erosion. The retreat rate of the permafrost-dominated coast has been steadily increasing due to the combined action of thermal and mechanical forces [1]. The total input of the intense coastal erosion to the Laptev Sea and the East Siberian Sea is estimated at 4.0 $-22.0 \pm 8.0 \mathrm{Tg}$ /year (the submarine permafrost degradation is included) [7,18]. Besides, the Lena River exports large volumes of the fresh water discharged to the Laptev Sea, being the main fluvial sediment source for the ESAS [19]. During the land-to-shelf transport, exported organic matter undergoes aerobic biochemical decomposition, which can be remineralized to $\mathrm{CO}_{2}$ or delivered to the deep-water part of the Arctic Ocean [8].

The Laptev Sea has a significant petroleum potential. It is considered an analogue of the North Sea Petroleum Basin, and a number of their common features have been identified. [20]. At the moment, no wells have been drilled offshore except for the Khatanga license area (Tsentralno-Olginskaya-1 well). Sampling points indicated in this manuscript are located within the Ust-Lenskiy license area owned by Rosneft.

Oil likely played a significant role in the phase composition of naphtides. Its formation in the land and coastal shelf zone was stipulated by the presence of high-quality oil source rocks in the Riphean-Phanerozoic cover of the Siberian Craton. In the rest the shelf, where the Aptian-Cenozoic rift system is widespread, oil can also be present in pools, since these rocks probably contain not only gas source rocks but also oil-and-gas bearing rocks of deltaic and prodeltaic age, which are located in the main oil formation zone. The above 
properties are specific features of the study region, and its hydrocarbon potential will be steadily increasing with the shelf development [21]. According to the results of the audit by DeGolyer and MacNaughton, as of 01.01.2019, the recoverable hydrocarbons reserves on the shelf of the Eastern Arctic amount to more than 13.7 bln toe net.

\subsection{Sample collection and preparation}

We analyzed 14 surface sediment samples (horizon $0-2 \mathrm{~cm}$ ) collected across the Laptev Sea shelf during the Arctic expedition onboard the Russian R/V Academician M. Keldysh during fall 2018 (Figure 1). A box corer was used to collect sediment samples. The sediment samples were immediately transferred to plastic bags after collection and then stored in a refrigerator at $-20^{\circ} \mathrm{C}$.

The sample preparationand analytical part of the research were carried out in the International Research Laboratory for Arctic Seas Carbon of the Tomsk Polytechnic University. The samples were thawed at room temperature for $24 \mathrm{~h}$, then brought to constant weight in a drying oven at $45^{\circ} \mathrm{C}$, and then homogenized.After this step, part of the samples was transmitted to theRock-Eval pyrolysis and Laser Diffraction to determine the particle size distribution. The rest of the surface sediment samples were subjected to further lipid biomarker analysis.

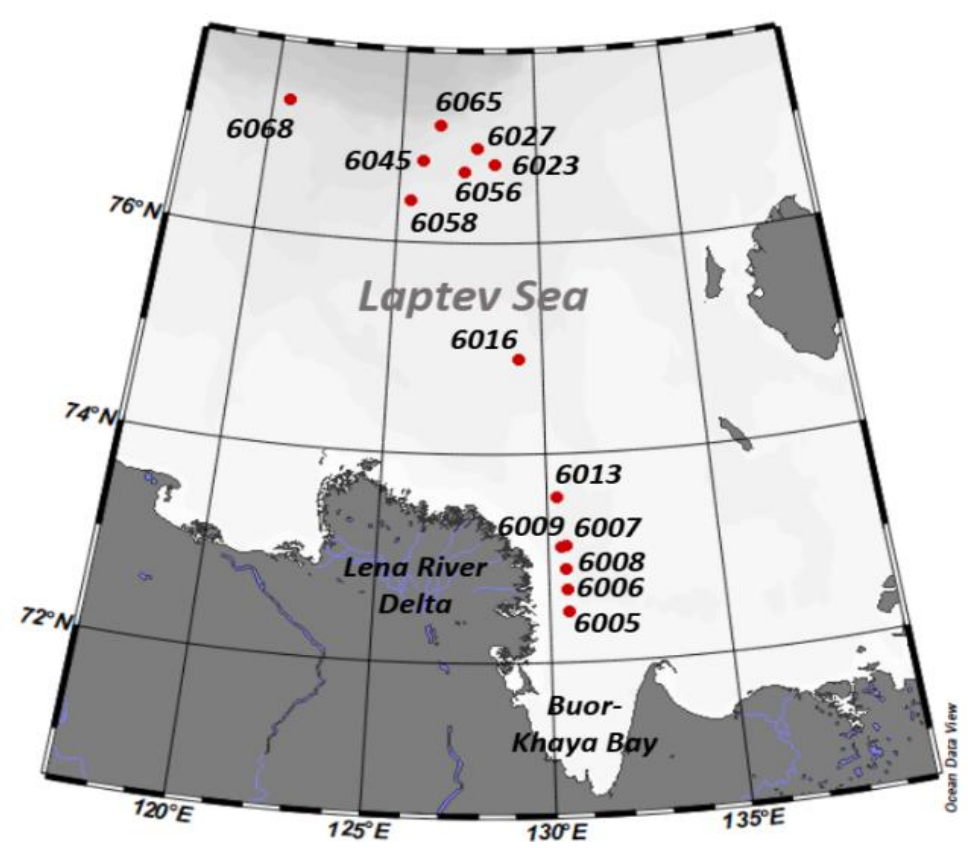

Fig. 1. Sample stations.

\subsection{Analytical methods}

\subsubsection{Rock-Eval Pyrolysis}

Pyrolytic analysis was performed on a Rock Eval 6 Turbo by Vinci Technologies. To provide relevant data for the modern $\mathrm{OM}$ an adapted Rock-Eval temperature program 
"Reservoir" was applied (start of sample heating at $+180^{\circ} \mathrm{C}$, holding for 10 minutes, then heating up to $+650^{\circ} \mathrm{C}$ at a rate of $25^{\circ} \mathrm{C} / \mathrm{min}$ ).

The peculiarity of the "Reservoir" program is the low initial pyrolysis temperature. A sample of about $40 \mathrm{mg}$ is kept under $180^{\circ} \mathrm{C}$ for 10 minutes. During this time, the released hydrocarbons are transported into the flame ionization detector by an inert gas stream, and thus the $\mathrm{S}_{1 \mathrm{r}}$ peak $(\mathrm{mg} \mathrm{HC} / \mathrm{g})$ is formed. Further heating from 180 to $650^{\circ} \mathrm{C}$ allows obtaining a double peak of $\mathrm{S}_{2 \mathrm{a}}(\mathrm{mg} \mathrm{HC} / \mathrm{g})$ and $\mathrm{S}_{2 \mathrm{~b}}(\mathrm{mg} \mathrm{HC} / \mathrm{g})$. The $\mathrm{S}_{1 \mathrm{r}}$ peak corresponds to the lightest fractions detected during the temperature plateau at $180^{\circ} \mathrm{C}$, whereas the $\mathrm{S}_{2 a}$ peak detects hydrocarbon compounds between 180 and $325^{\circ} \mathrm{C}$ [22]. The $\mathrm{S}_{2 \mathrm{~b}}$ peak is assigned to the cracking of geopolymers. The temperature of the highest hydrocarbon yield rate (during the formation of the $\mathrm{S}_{2 \mathrm{~b}}$ peak) is denoted as $\mathrm{T}_{\text {peak }}\left({ }^{\circ} \mathrm{C}\right)$.

In addition to the pyrolysis oven, the Rock-Eval 6 Turbo is equipped with an oxidation oven and two infrared cells for registering $\mathrm{CO}$ and $\mathrm{CO}_{2}$ gases emitted during pyrolysis and oxidation. The registration of $\mathrm{CO}$ and $\mathrm{CO}_{2}$ provides information on the $\mathrm{OM}$ oxidation degree $\left(\mathrm{S}_{3}\right.$ peak, $\left.\mathrm{mg} \mathrm{CO}_{2} / \mathrm{g}\right)$.

Based on the determined pyrolysis parameters $\left(\mathrm{S}_{1 \mathrm{r}}, \mathrm{S}_{2 \mathrm{a}}\right.$, etc. $)$, the amount of pyrolyzed organic carbon (PC, wt\%) is calculated.

An additional oxidation stage allows to calculate the hydrogen ( $\mathrm{HI}, \mathrm{mg} \mathrm{HC} / \mathrm{g} \mathrm{C}_{\text {org }}$ ) and oxygen (OI, $\mathrm{mg} \mathrm{CO}_{2} / \mathrm{g} \mathrm{C}_{\text {org }}$ ) indices, residual organic carbon $(\mathrm{RC}, \mathrm{wt} \%$ ), total organic (TOC, wt $\%)_{2}$ and mineral carbon (MinC, wt \%) in the rock samples.

To make our data consistent with previously published studies [22,23], the following equations are applied: $\mathrm{S}_{1}=\mathrm{S}_{1 \mathrm{r}}+\mathrm{S}_{2 \mathrm{a}}$ and $\mathrm{S}_{2}=\mathrm{S}_{2 \mathrm{~b}}$.

\subsubsection{Laser Diffraction}

The particle size distribution was determined by the laser diffraction SALD-7101 Shimadzu. A weighed part of the test sample was placed in a mixer bath with distilled water and dispersed using an ultrasonic setup (40 W, $40 \mathrm{kHz})$. Measurements were performed in a flow-through cell. Shepard's "sand-silt-clay" classification was applied: sand (>63 $\mu \mathrm{m})$, silt (from 2 to $63 \mu \mathrm{m}$ ), and clay $(<2 \mu \mathrm{m}$ ).

\subsubsection{Gas Chromatography-Mass Spectrometry}

Dried and homogenized samples were extracted using Soxhlet extraction with chloroform for 16 hours. The total lipid extracts (TLE) were concentrated using a rotary evaporatot. Sodium sulfate and activated copper powder were added to remove water and elemental sulfur, respectively. Then, $\sim 10 \mathrm{mg}$ of internal standard (d50-tetracosane) was added. The extracts were analyzed by a GC-MS (Agilent 7890B (GC) - Agilent Q-TOF 7200 (MS)). Quantification was performed using a five-point calibration curve with commercially available standards.

\section{Results}

\subsection{Rock-Eval Pyrolysis}

According to the pyrolysis data, total organic carbon (TOC) varies from 0.4 to $2.71 \mathrm{wt} \%$, which is consistent with previous studies in the region [24]. Free hydrocarbons and low molecular weight $\mathrm{OM}$, considered as lipid fraction $\left(\mathrm{S}_{1}\right)$, range from 0.11 to $0.73 \mathrm{mg} \mathrm{HC} / \mathrm{g}$ (Table 1) $[23,25,26]$. The predominantly higher TOC and $\mathrm{S}_{1}$ values are found in the coastal zone (> $1 \mathrm{wt} \%$ and $>0.4 \mathrm{mg} \mathrm{HC} / \mathrm{g}$, respectively) (Figure 2). 
Table 1. Rock-Eval parameters for Laptev Sea surface sediments.

\begin{tabular}{|c|c|c|c|c|c|c|c|c|c|c|}
\hline Statio & $\mathrm{S}_{1}$ & $\mathrm{~S}_{2}$ & $\mathrm{~S}_{3}$ & $\begin{array}{l}\mathrm{T}_{\text {pea }} \\
\mathrm{k}\end{array}$ & $\mathrm{PC}$ & $\mathrm{RC}$ & $\begin{array}{l}\text { TO } \\
\mathrm{C} \\
\end{array}$ & HI & OI & $\begin{array}{l}\text { Min } \\
\mathrm{C} \\
\end{array}$ \\
\hline$n$ & $\begin{array}{l}\mathrm{mg} \\
\mathrm{HC} / \mathrm{g}\end{array}$ & $\begin{array}{l}\mathrm{mg} \\
\mathrm{HC} / \mathrm{g}\end{array}$ & $\begin{array}{l}\mathrm{mg} \\
\mathrm{HC} / \mathrm{g}\end{array}$ & ${ }^{\circ} \mathrm{C}$ & $\begin{array}{l}\mathrm{wt} \\
\%\end{array}$ & $\begin{array}{l}\text { wt } \\
\%\end{array}$ & $\begin{array}{l}\mathrm{wt} \\
\%\end{array}$ & $\begin{array}{l}\mathrm{mg} \quad \mathrm{HC} / \mathrm{g} \\
\mathrm{C}_{\text {org }}\end{array}$ & $\begin{array}{l}\mathrm{mg} \quad \mathrm{HC} / \mathrm{g} \\
\mathrm{C}_{\text {org }}\end{array}$ & $\mathrm{wt} \%$ \\
\hline 6005 & 0.37 & 1.78 & 3.02 & 461 & $\begin{array}{l}0.2 \\
8\end{array}$ & $\begin{array}{l}1.1 \\
4\end{array}$ & $\begin{array}{l}1.4 \\
2\end{array}$ & 125 & 213 & 0.2 \\
\hline 6006 & 0.65 & 2.92 & 5.74 & 462 & 0.5 & $\begin{array}{l}2.2 \\
1\end{array}$ & $\begin{array}{l}2.7 \\
1\end{array}$ & 108 & 212 & 0.4 \\
\hline 6007 & 0.73 & 2.74 & 5.32 & 462 & $\begin{array}{l}0.6 \\
4\end{array}$ & $\begin{array}{l}2.0 \\
1\end{array}$ & $\begin{array}{l}2.6 \\
5\end{array}$ & 103 & 201 & 0.4 \\
\hline 6008 & 0.71 & 2.61 & 4.82 & 462 & $\begin{array}{l}0.4 \\
8\end{array}$ & $\begin{array}{l}1.7 \\
9\end{array}$ & $\begin{array}{l}2.2 \\
7\end{array}$ & 115 & 212 & 0.3 \\
\hline 6009 & 0.53 & 1.98 & 3.84 & 461 & $\begin{array}{l}0.3 \\
5\end{array}$ & $\begin{array}{l}1.5 \\
8\end{array}$ & $\begin{array}{l}1.9 \\
3\end{array}$ & 103 & 199 & 0.3 \\
\hline 6013 & 0.28 & 1.12 & 1.92 & 464 & $\begin{array}{l}0.2 \\
1\end{array}$ & $\begin{array}{l}0.7 \\
4\end{array}$ & $\begin{array}{l}0.9 \\
5\end{array}$ & 118 & 202 & 0.2 \\
\hline 6016 & 0.39 & 1.52 & 3.38 & 459 & $\begin{array}{l}0.3 \\
7\end{array}$ & $\begin{array}{l}1.0 \\
1\end{array}$ & $\begin{array}{l}1.3 \\
8\end{array}$ & 110 & 245 & 0.2 \\
\hline 6027 & 0.17 & 1.01 & 1.98 & 453 & $\begin{array}{l}0.1 \\
7\end{array}$ & $\begin{array}{l}0.4 \\
7\end{array}$ & $\begin{array}{l}0.6 \\
4\end{array}$ & 158 & 309 & 0.2 \\
\hline 6045 & 0.33 & 1.22 & 1.86 & 380 & 0.2 & $\begin{array}{l}0.5 \\
9\end{array}$ & $\begin{array}{l}0.7 \\
9\end{array}$ & 154 & 235 & 0.2 \\
\hline 6053 & 0.34 & 1.52 & 3.32 & 390 & $\begin{array}{l}0.2 \\
8\end{array}$ & $\begin{array}{l}0.9 \\
8\end{array}$ & $\begin{array}{l}1.2 \\
6\end{array}$ & 121 & 263 & 0.2 \\
\hline 6056 & 0.19 & 1 & 1.75 & 382 & $\begin{array}{l}0.1 \\
6\end{array}$ & $\begin{array}{l}0.5 \\
4\end{array}$ & 0.7 & 143 & 250 & 0.2 \\
\hline 6058 & 0.11 & 0.87 & 1.3 & 459 & $\begin{array}{l}0.1 \\
3\end{array}$ & $\begin{array}{l}0.3 \\
5\end{array}$ & $\begin{array}{l}0.4 \\
8\end{array}$ & 181 & 271 & 0.1 \\
\hline 6065 & 0.11 & 0.67 & 1.18 & 392 & $\begin{array}{l}0.1 \\
1\end{array}$ & $\begin{array}{l}0.2 \\
9\end{array}$ & 0.4 & 168 & 295 & 0.1 \\
\hline 6068 & 0.19 & 0.92 & 2 & 395 & $\begin{array}{l}0.1 \\
6 \\
\end{array}$ & $\begin{array}{l}0.5 \\
3 \\
\end{array}$ & $\begin{array}{l}0.6 \\
9 \\
\end{array}$ & 133 & 290 & 0.2 \\
\hline
\end{tabular}

Parameters $\mathrm{T}_{\text {peak }}, \mathrm{S}_{1}, \mathrm{~S}_{2}, \mathrm{~S}_{3}, \mathrm{PC}, \mathrm{RC}, \mathrm{TOC}, \mathrm{HI}$, OI, MinC are explained in the text (Section 2.3.1).

The contents of relatively thermo-labile hydrogen-rich $\mathrm{OM}$ or biopolymers $\left(\mathrm{S}_{2}\right)$ and $\mathrm{CO} / \mathrm{CO}_{2}$, released by oxygen-containing $\mathrm{OM}$ or geopolymers $\left(\mathrm{S}_{3}\right)$, correspond to $0.67-$ $2.92 \mathrm{mg} \mathrm{HC} / \mathrm{g}$ and to $1.18-5.4 \mathrm{mg} \mathrm{HC} / \mathrm{g}$, respectively (Table 1) [23,25,26]. Consequently, the fraction of the lipid extractable component in the total OM yield is, on average, 13 times less than the fraction of biogeopolymers stored in the sediments $\left(\mathrm{S}_{2}+\mathrm{S}_{3}\right)$.

The fraction of mineral carbon (MinC) is significantly less than the TOC and varies from 0.09 to $0.38 \mathrm{wt} \%$, with the correlation between the TOC and MinC arrays close to 1 . 
The sediment distribution suggests a relatively low HI (hydrogen index) and a higher OI (oxygen index). The hydrogen index of all samples is higher than $100 \mathrm{mg} \mathrm{HC} / \mathrm{g} \mathrm{C}_{\text {org }}$ and ranges from 103 to $181 \mathrm{mg} \mathrm{HC/g} \mathrm{C}_{\text {org }}$, which indicates the presence of a hydrobiont component in the OM. The maximum HI values are recorded in the samples taken from the outer shelf. Consequently, they are characterized by a hypoxic or anoxic sedimentation environment, in contrast to the coastal samples, where intensive resuspension may induce oxidation of the sedimentary OM.

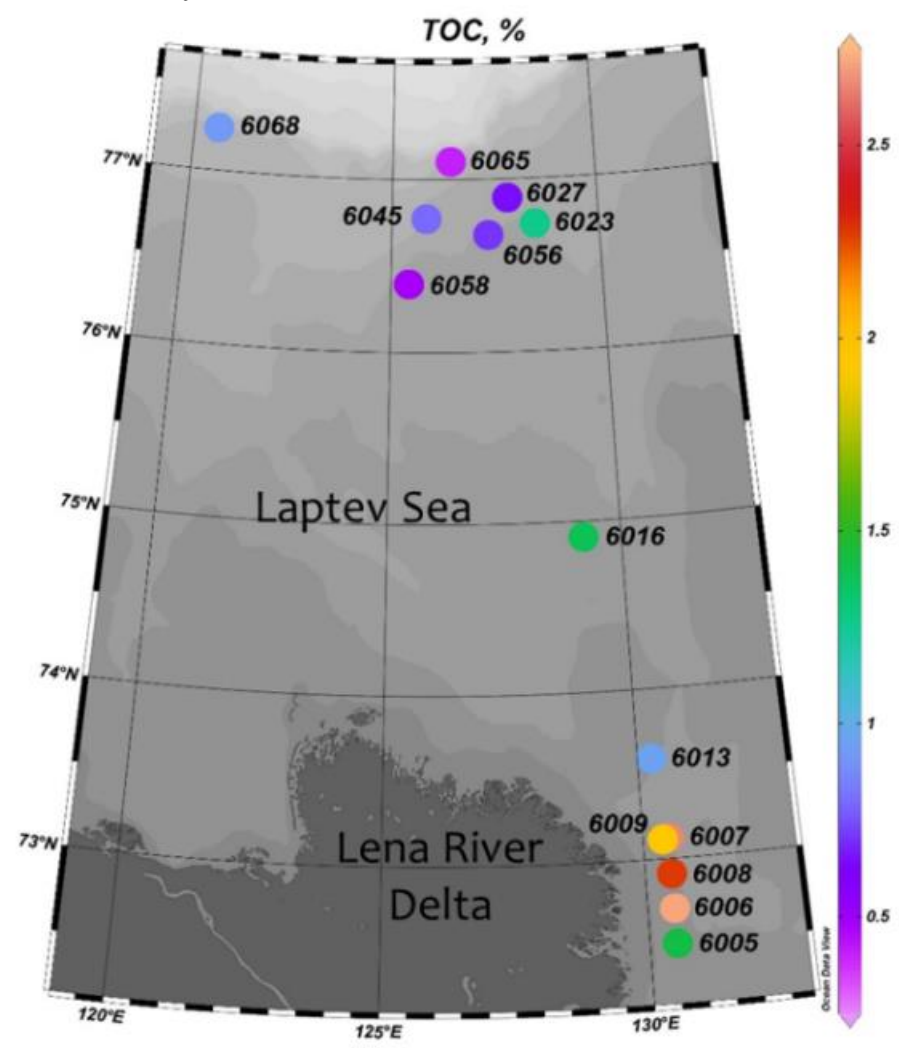

Fig. 2. Total Organic Carbon (TOC), w\% values of surface sediments across the Laptev Sea shelf.

The OI ranges from 199 to $309 \mathrm{mg} \mathrm{HC/g} \mathrm{Corg}$. The OI can reflect both the export of already oxidized OM with river runoff and coastal erosion and the subsequent degradation of allochthonous and autochthonous OM in the water column, as far as it is buried in sediments; therefore, it is important to separate these two processes.

$\mathrm{T}_{\text {peak }}$ varies from 380 to $464^{\circ} \mathrm{C}$, which is $64 \%$ higher than the $\mathrm{T}_{\text {peak }}$ boundary for modern sediments $\left(<425^{\circ} \mathrm{C}\right)$ [27]. The studied samples can be divided into two clusters according to the $\mathrm{T}_{\text {peak }}$ ranges: 1) $380-395^{\circ} \mathrm{C}$ and 2) $453-464^{\circ} \mathrm{C}$. The first range corresponds to the temperatures of destruction of polysaccharides and lignin (terrigenous $\mathrm{OM}$ ), the second temperature window indicates the dominance of humic and fulvic acids in the $\mathrm{OM}$ composition [23].

A classical presentation of RE data is in the form of a pseudo-Van Krevelen diagram, which plots the $\mathrm{OI}$ and $\mathrm{HI}$ against each other in a manner analogous to the atomic $\mathrm{O} / \mathrm{C}$ and $\mathrm{H} / \mathrm{C}$ ratios used to classify kerogens $[23,28]$. The ratio diagram of hydrogen and oxygen indices (HI/OI) is shown in Figure 3. 

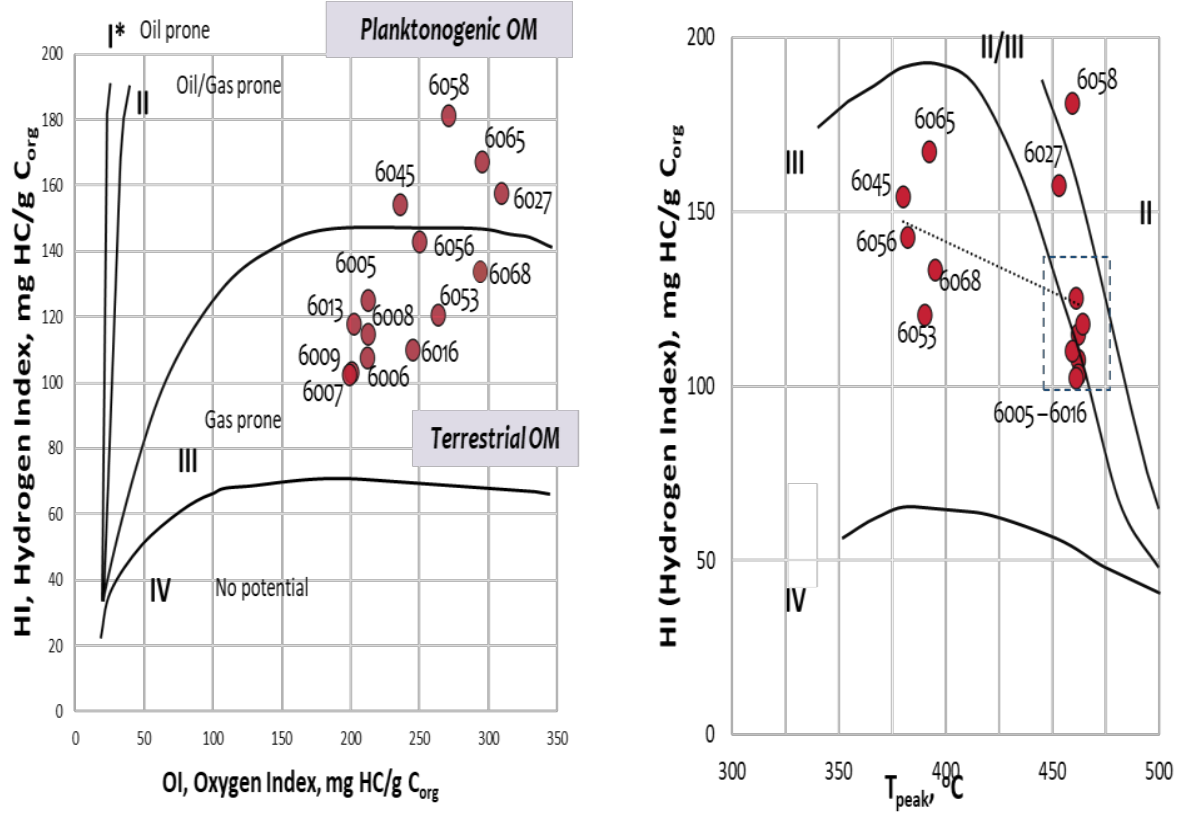

Fig. 3. Left: Modified Van Krevelen-type diagram of surface sediments across the Laptev Sea shelf.

Right: $\mathrm{HI}, \mathrm{mg} \mathrm{HC} / \mathrm{g} \mathrm{C}_{\text {org }}$ as a function of $\mathrm{T}_{\text {peak }},{ }^{\circ} \mathrm{C}$.

Ratio HI/OI < 1 may be compared to a mix of "Type 2" and "Type 3" kerogens for matured OM determining planktonogenic and terrestrial origin, respectively. The samples taken from the coastal part show the dominant terrestrial originof OM. However, the contribution of autochthonous OM is clearly traced for the outer shelf samples. The $\mathrm{T}_{\text {peak }} /$ HI ratio, shown in Figure 3, also confirms these statements [17].

The RE parameters reflect the genesis of OM (of marine or terrigenous origin), as well as the degree of dia- and catagenesis OM transformation. For surface sediments, $\mathrm{S}_{1}, \mathrm{~S}_{2}, \mathrm{~S}_{3}$, $\mathrm{RC}$, and $\mathrm{T}_{\text {peak }}$ are the most informative. Relatively high values of $\mathrm{S}_{1}$ and $\mathrm{S}_{2}$ characterize the marine primary production, while high $\mathrm{S}_{3}$ and residual carbon $(\mathrm{RC})$ correspond to terrestrial organic material. These features are due to the marine OM composition: a low concentration or absence of lignin (an oxygen-containing polymer, which has terrestrial origin) and a high lipid content.

During the process of sediment transportation and resuspension coupled with OM oxidation (degradation), the proportion of oxygen-containing compounds increases, while the content of hydrogen decreases. It is directly reflected in the HI and OI indexes corresponding to the degree of OM transformation [23]. Thus, the "fresh" OM of modern sediments is characterized by high values of the HI/OI parameter $(>2)$; whereas the HI/OI values decrease for degraded OM.

\subsection{Grain-Size distribution}

The lithological type of sediments was based on the Shepard's "sand-silt-clay" rations [29]. According to the grain size analysis, sediments are dominated by clay $(<2 \mu \mathrm{m})$ and silt $(2-$ $63 \mu \mathrm{m})$ fractions. The sand fraction $(>63 \mu \mathrm{m})$ is almost absent (Table 2). 
Table 2. Grain-size characteristics of surface sediments.

\begin{tabular}{llllllll}
\hline \multirow{2}{*}{$\begin{array}{l}\text { Sampling } \\
\text { station }\end{array}$} & Latitude & Longitude & Depth & $\begin{array}{l}\text { Sand } \\
(>63 \mu \mathrm{m})\end{array}$ & $\begin{array}{l}\text { Silt } \\
(2-63 \\
\mu \mathrm{m})\end{array}$ & $\begin{array}{l}\text { Clay } \\
(<2 \\
\mu \mathrm{m})\end{array}$ & $\begin{array}{l}\text { Lithological } \\
\text { type }\end{array}$ \\
\cline { 5 - 7 } & & & $\mathrm{m}$ & $\mathrm{w} \%$ & $\mathrm{w} \%$ & $\mathrm{w} \%$ & \\
\hline 6005 & 72.5000 & 130.4990 & 14.5 & 0.2 & 38.1 & 61.7 & Silty clay \\
6006 & 72.7070 & 130.4990 & 18.5 & 0.1 & 69.3 & 30.6 & Clayey silt \\
6007 & 73.1230 & 130.5000 & 24.3 & 0 & 79.3 & 20.7 & Silt \\
6008 & 72.9110 & 130.5000 & 22 & 0 & 73.2 & 26.8 & Silt \\
6009 & 73.1150 & 130.3740 & 24 & 0 & 71.5 & 28.5 & Silt \\
6013 & 73.5930 & 130.2760 & 23.5 & 0 & 44.9 & 55.1 & Silty clay \\
6016 & 74.9080 & 129.1890 & 40 & 0.1 & 76.8 & 23.1 & Silt \\
6027 & 76.8920 & 127.7970 & 64 & 0.1 & 43.5 & 56.4 & Silty clay \\
6045 & 76.7750 & 125.8290 & 72 & 0 & 55.9 & 44.1 & Clayey silt \\
6053 & 76.7390 & 128.4530 & 65 & 0 & 69.4 & 30.6 & Clayey silt \\
6056 & 76.6790 & 127.3170 & 62 & 0 & 59.3 & 40.7 & Clayey silt \\
6058 & 76.3960 & 125.4190 & 52 & 0 & 41.9 & 58.1 & Silty clay \\
6065 & 77.1030 & 126.4240 & 251 & 0.1 & 9.3 & 90.6 & Clay \\
6068 & 77.2460 & 120.6140 & 185 & 0 & 73.4 & 26.6 & Silt \\
\hline
\end{tabular}

The positive correlation between HI and clay content $(r=0.71)$ is higher than the connection between OI and clay fraction $(\mathrm{r}=0.42)$ (Figure 4$)$.
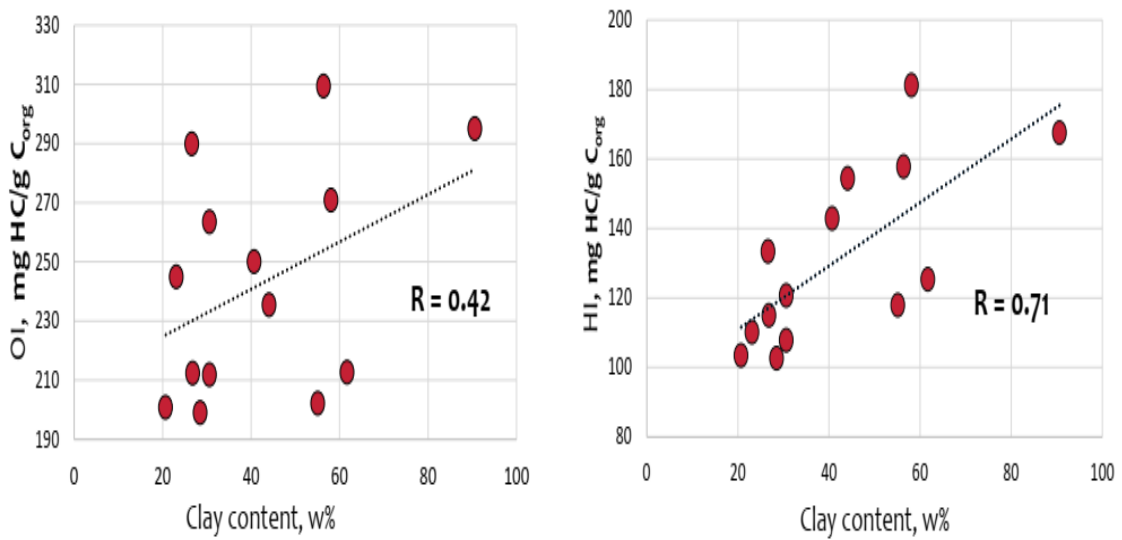

Fig. 4. OI, $\mathrm{mg} \mathrm{HC} / \mathrm{g} \mathrm{C}$ org and $\mathrm{HI}, \mathrm{mg} \mathrm{HC/g} \mathrm{C}_{\text {org }}$ as a function of clay content, w\%.

It suggests that clay particles may create a favorable depositional environment, and, therefore, partly preserve the mineral-associated OM from oxidation. Nevertheless, we would not mention the mineral matrix as a first-order control factor for OM preservation.

\subsection{GC-MS records}

\subsubsection{Qualitative interpretation of $n$-alkanes distribution}

Currently, the study focuses on the qualitative interpretation of n-alkanes (neutral non-polar fraction) and isoprenoids (pristane and phytane) distribution. Obviously, terrestrial input is a main contributor to the $\mathrm{OM}$ of the studied sediments. Overall dominance of the high molecular weight (HMW) odd $\mathrm{C}_{25}-\mathrm{C}_{31}$ n-alkanes indicates a significant portion of 
terrestrial OM exported with river discharge and thermo abrasion material [7,30]. However, for many outer shelf samples both the hydrobiont markers of the autochthonous nature $\left(\mathrm{C}_{15}\right.$ $\mathrm{C}_{19}$ n-alkanes) and the terrestrial markers mentioned before are contrastingly expressed.

Such classic geochemical indices were calculated based on the peak exit areas on received chromatograms: CPI (Carbon Preference Index), OEP $17, \mathrm{OEP}_{19}$ (Odd Even Predominance) indexes, $\mathrm{K}_{\mathrm{i}}$, TAR (terrigenious to aquatic ratio), Paq, and $\mathrm{Pr} / \mathrm{Phy}$ ratio (Table 3).

Table 3. Geochemical Indexes based on GC-MS records.

\begin{tabular}{|c|c|c|c|c|c|c|c|}
\hline Sample & $\mathrm{CPI}^{*}$ & $\mathrm{Ki}$ & $\mathrm{OEP}_{17}$ & $\mathrm{OEP}_{19}$ & TAR & $\mathrm{Paq}$ & $\mathrm{Pr} / \mathrm{Phy}$ \\
\hline 6005 & -** $^{* *}$ & 0.37 & 1.23 & 1.24 & 18.87 & 0.37 & 1.42 \\
\hline 6006 & 7.25 & 0.34 & 1.19 & 1.37 & 33.45 & 0.36 & 1.82 \\
\hline 6008 & 7.75 & 0.34 & 2.05 & 1.60 & 37.64 & 0.34 & 2.27 \\
\hline 6009 & 7.25 & 0.43 & 1.73 & 1.40 & 36.29 & 0.32 & 1.30 \\
\hline 6013 & 5.33 & 0.61 & - & 1.07 & - & 0.30 & 1.10 \\
\hline 6016 & - & 0.48 & - & 1.24 & - & 0.31 & 1.13 \\
\hline 6027 & - & 0.54 & 1.12 & 1.32 & 6.25 & 0.28 & 2.88 \\
\hline 6045 & - & 0.62 & 1.14 & 1.13 & 10.27 & 0.30 & 1.69 \\
\hline 6053 & 5.31 & 0.39 & 0.86 & 1.08 & 10.70 & 0.27 & 1.96 \\
\hline 6056 & - & 0.67 & 1.10 & 1.03 & 11.85 & 0.24 & 2.23 \\
\hline 6058 & 5.09 & 0.13 & 0.90 & 1.12 & 0.95 & 0.26 & 1.78 \\
\hline 6065 & 3.77 & 0.63 & 1.33 & 1.72 & 5.31 & 0.35 & 1.03 \\
\hline 6068 & - & - & - & - & - & 0.29 & - \\
\hline $\begin{array}{l}{ }^{*} \mathrm{CPI}=0 \\
+\mathrm{nC}_{29}+ \\
\mathrm{Ki}=(\mathrm{Pr} \\
\mathrm{OEP}_{17}= \\
\mathrm{OEP}_{19}= \\
\mathrm{TAR}= \\
\mathrm{Paq}=(\mathrm{n} \\
* *-(\text { the }\end{array}$ & $\begin{array}{l}{ }^{6}\left[\left(\mathrm{nC}_{2}\right.\right. \\
31+\mathrm{nC} \\
\mathrm{hy}) /(\mathrm{nC} \\
\mathrm{c}^{15}+6 \\
\mathrm{C}_{17}+6 \\
7+\mathrm{nC}_{2} \\
+\mathrm{nC}_{25} \\
\text { no wa }\end{array}$ & $\begin{array}{l}27+\mathrm{nC} \\
\mathrm{C}_{26}+\mathrm{n} \\
\left.\mathrm{C}_{18}\right) . \\
+\mathrm{nC}_{1} \\
+\mathrm{nC}_{2} \\
-31) /(\mathrm{nC} \\
3+\mathrm{C}_{25} \\
\text { alculate }\end{array}$ & $\begin{array}{l}\mathrm{C}_{31}+\mathrm{nC} \\
\mathrm{nC}_{30}+\mathrm{n} \\
\mathrm{nC}_{16}+ \\
\mathrm{nC}_{18}+ \\
\mathrm{C}_{17}+\mathrm{nC} \\
\left.+\mathrm{C}_{31}\right) . \\
\text { dex fron }\end{array}$ & $\begin{array}{l}\left(\mathrm{nC}_{24}+\mathrm{n}\right. \\
\left.\left.\mathrm{nC}_{34}\right)\right] . \\
\left.\mathrm{C}_{18}\right) . \\
\left.\mathrm{C}_{20}\right) . \\
\text { obtained }\end{array}$ & kanes & ution) & $\mathrm{C}_{25}+\mathrm{nC}$ \\
\hline \multicolumn{8}{|c|}{$\begin{array}{l}\text { The predominance of odd-number carbon atoms n-alkanes over their even homologues } \\
\text { was evaluated by the CPI and OEP indices. } \mathrm{K}_{\mathrm{i}} \text { demonstrates the degree of diagenetic } \\
\text { transformation and increases with maturity. The TAR determines the genesis of the initia } \\
\text { OM, and Paq index reflects the contribution of aquatic macrophytes. The paramount ratic } \\
\text { of pristane to phytane gives information about the redox potential of the sedimentation } \\
\text { environment. }\end{array}$} \\
\hline
\end{tabular}


High values of the CPI ( $>3$ ) indicate a prevalence of vascular land plants as a source of OM and low microbial degradation state. The average Ki (0.46) and OEP (1.28) indexes also confirm low diagenetic transformation of OM. The TAR traces an increasing supply of autochtonous OM with increasing distance from the coast. In the zone of coastal sediments, the terrestrial component is clearly pronounced (TAR $=31.6$ ), while for the outer shelf sediments, the index is 4 times lower $(\mathrm{TAR}=7.6)$ (Figure 5). The Paq index points out a low contribution of macrophytes $(\mathrm{Paq}=0.31)$ with increasing values in the coastal part. The Pr/Phy ratio confirms the suboxidative environment revealed by the pyrolysis data (HI/OI ratio).

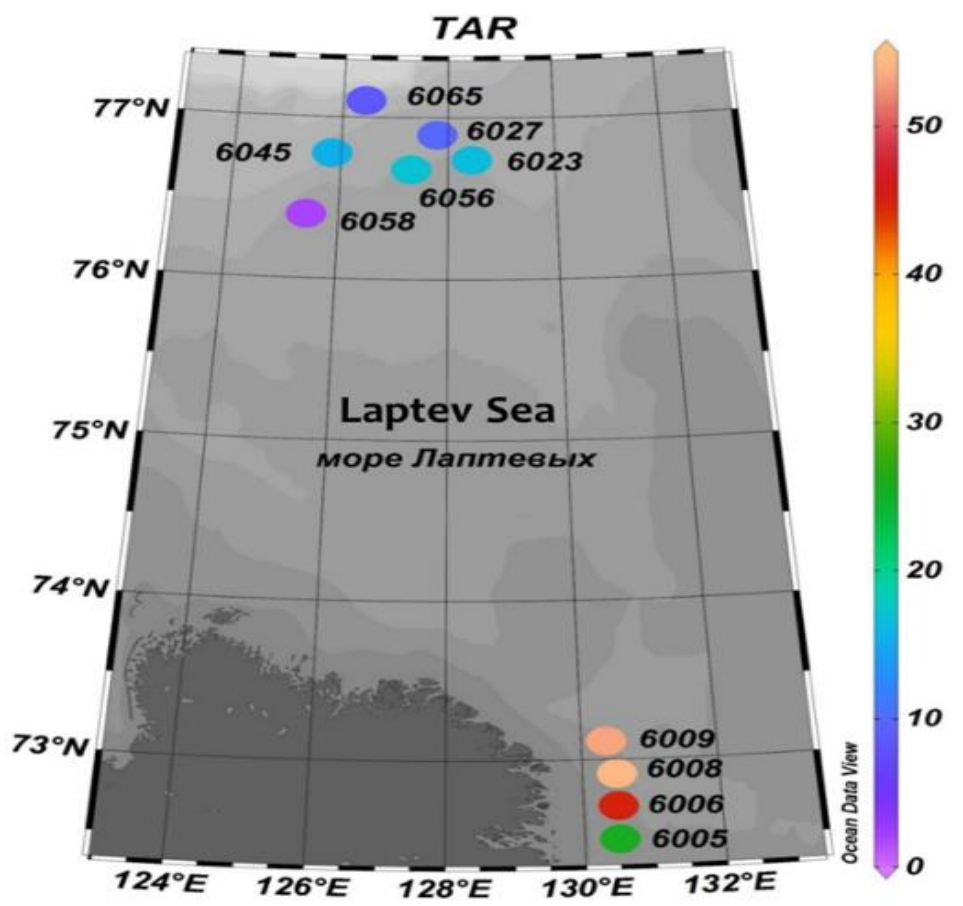

Fig.5.TAR(terrigenous to aquatic ratio) index values of surface sediments across the Laptev Sea shelf.

\section{Conclusions}

The content of TOC in the studied samples varies from 0.40 to $2.73 \%$, while the PC in the total volume of TOC is 20 to $30 \%$. The lipid $\left(\mathrm{S}_{1}\right)$ fraction in the total OM yield is on average 13 times less than the sum of biogeopolymers $\left(S_{2}+S_{3}\right)$.

Surface sediments correspond to clay, silt, and their mixed fractions. A significant positive correlation was established between the clay content and the hydrogen index (HI). It suggests that clay particles may create a favorable depositional environment, and, therefore, partly preserve the mineral-associated OM from oxidation.

The OM of surface sediments is divided into two types: the coastal OM predominantly has a terrestrial source; the outer shelf $\mathrm{OM}$ is characterized as a mixed allochthonousautochthonous type. Overall, the decisive contribution to the OM composition is provided by terrestrial sources: river runoff and coastal erosion.

In general, the GC-MS records are directly comparable to the Rock-Eval data. Along the studied profile, the contribution of the terrestrial $\mathrm{OM}$ in the outer shelf surface sediments is clearly traced despite the great distance from the coastal zone. This is a distinctive feature of the Laptev Sea biogeochemical regime, which was previously noted 
by other researchers [8,9]. Our results confirm and enhance their findings with new geochemical data providing an additional piece towards a deeper understanding of the modern biogeochemical carbon cycle in the Arctic.

With regard to the applied aspect, we plan to identify compounds of naphthydogenic nature, which are markers of the hydrocarbon depth migration, in the key of geochemical prospecting methods. These anomalies can be used to identify areas with the potential presence of hydrocarbon deposits.

This research is supported by the Russian Science Foundation, project \# 19-77-00067 (Rock-Eval analysis, grain size analysis, interpretation of the results) and the Tomsk Polytechnic University Competitiveness Enhancement Program (sampling) and the President of the Russian Federation Grant for young candidates of science \# MK-535.2020.5 (GC-MS analysis).

\section{References}

1. F. Günther, P.P. Overduin, A.V. Sandakov, G. Grosse, M.N. Grigoriev, Short- and long-term thermo-erosion of ice-rich permafrost coasts in the Laptev Sea region.Biogeosciences, 10: 4297 - 4318 (2013).

2. N. Shakhova, I. Semiletov, O. Gustafsson, V. Sergienko, L. Lobkovsky, O. Dudarev, V. Tumskoy, M. Grigoriev, A. Mazurov, A. Salyuk, R. Ananiev, A. Koshurnikov, D. Kosmach, A. Charkin, N. Dmitrevsky, V. Karnaukh, A. Gunar, A. Meluzov, D. Chernykh, Current rates and mechanisms of subsea permafrost degradation in the East Siberian Arctic Shelf. Nature Communications, 8, 15872 (2017).

3. F.S. Chapin, M. Torn, M. Tateno, Principles of Ecosystem Sustainability. American Naturalists, 148(6): 1016-1037 (1996).

4. H. Meltofte, Arctic Biodiversity Assessment. Status and Trends in Arctic Biodiversity. Conservation of Arctic Flora and Fauna (Akureyri: Iceland, 2013).

5. I. Semiletov, I. Pipko, Ö. Gustafsson, L.G. Anderson, V. Sergienko, S. Pugach, O. Dudarev, A. Charkin, A. Gukov, L. Bröder, A. Andersson, E. Spivak, N. Shakhova, Acidification of East Siberian Arctic Shelf waters through addition of freshwater andterrestrial carbon. Nature Geoscience, 9: 361-365 (2016).

6. D.W. Capelle, A. Kuzyk Zou Zou, T. Papakyriakou, C. Guéguen, L.A. Miller, R.W. Macdonald, Effect of terrestrial organic matter on ocean acidification and CO2 flux in an Arctic shelf sea, Progress in Oceanography, 185: 102319 (2020).

7. J.E. Vonk, L. Sánchez-García, B.E. Van Dongen, V. Alling, D. Kosmach, A. Charkin, I.P. Semiletov, O.V. Dudarev, N. Shakhova, P. Roos, T.I. Eglinton, A. Andersson, Ö. Gustafsson, Activation of old carbon by erosion of coastal and subsea permafrost in Arctic Siberia. Nature 489(7414): 137-140 (2012).

8. L. Bröder, T. Tesi, J. A. Salvadó, I. Semiletov, O. Dudarev, Ö. Gustafsson, Fate of terrigenous organic matter across the Laptev Sea from the mouth of the Lena River to the deep sea of the Arctic interior, Biogeosciences, 13: 5003-5019 (2017).

9. L. Bröder, A. Andersson, T. Tesi, I. Semiletov, Ö. Gustafsson, Quantifying degradative loss of terrigenous organic carbon in surface sediments across the Laptev and East Siberian Sea. Global Biogeochemical Cycles, 33: 85-99 (2019).

10. E.S. Karlsson, A. Charkin, O. Dudarev, I. Semiletov, J.E. Vonk, L. Sánchez-García, A. Andersson, Ö. Gustafsson, Carbon isotopes and lipid biomarker investigation of sources, transport and degradation of terrestrial organic matter in the Buor-Khaya Bay, SE Laptev Sea, Biogeosciences, 8: 1865-1879 (2011). 
11. J.A. Salvadó, T. Tesi, M. Sundbom, E. Karlsson, M. Kruså, I.P. Semiletov, E. Panova, Ö. Gustafsson, Contrasting composition of terrigenous organic matter in the dissolved, particulate and sedimentary organic carbon pools on the outer East Siberian Arctic Shelf. Biogeosciences, 13: 6121-6138 (2016).

12. S.H. Ahn, K.W. Kim, J. Naeun, J.J. Kang, J.H. Lee, T.E. Whitledge, D.A. Stockwell, H.W. Lee, S.H. Lee, Fluvial influence on the biochemical composition of particulate organic matter in the Laptev and Western East Siberian seas during 2015. Marine Environmental Research, 155: 104873 (2020).

13. N. Shakhova, I. Semiletov, A. Salyuk, V. Yusupov, D. Kosmach, O. Gustafsson, Extensive methane venting to the atmosphere from sediments of the East Siberian Arctic Shelf. Science 327: 1246-1250 (2010).

14. N.E. Shakhova, I.P. Semiletov, I. Leifer, V. Sergienko, A. Salyuk, D. Kosmach, D. Chernykh, C. Stubbs, D. Nicolsky, V. Tumskoy, Ö. Gustafsson, Ebullition and storminduced methane release from the East Siberian Arctic Shelf. Nature Geoscience, 7(1): 64-70 (2014).

15. N.E. Shakhova, I.P. Semiletov, V. Sergienko, L. Lobkovsky, V. Yusupov, A. Salyuk, A. Salomatin, D. Chernykh, D. Kosmach, G. Panteleev, D. Nicolsky, V. Samarkin, S. Joye, A. Charkin, O. V. Dudarev, A., Meluzov, O. Gustafsson, The East Siberian Arctic Shelf: Towards further assessment of permafrost-related methane fluxes and role of sea ice. Philosophical Transactions of the Royal Society A: Mathematical, Physical and Engineering Sciences 373, 2052 (2015).

16. L. Sánchez-García, V. Alling, S. Pugach, J., Vonk, B. Van Dongen, C. Humborg, O. Dudarev, I. Semiletov, Ö. Gustafsson, Inventories and behavior of particulate organic carbon in the Laptev and East Siberian seas. Global Biogeochem 25: GB2022 (2011).

17. R. Stein, and R. W. Macdonald, The organic carbon cycle in the Arctic Ocean. (Springer Verlag, 2004).

18. V. Rachold, M.N. Grigoriev, F.E. Are, S. Solomon, E. Reimnitz, H. Kassens, M. Antonow, Coastal erosion vs riverine sediment discharge in the Arctic Shelf seas. International Journal of Earth Sciences, 89: 450-459 (2000).

19. R.M. Holmes, J.W. McClelland, B.J. Peterson, I.A. Shiklomanov, A.I. Shiklomanov, A.V. Zhulidov, V.V. Gordeev, N.N. Bobrovitskaya, A circumpolar perspective on fluvial sediment flux to the Arctic ocean. Global Biogeochemical Cycles, 16(4): 14-45. (2002).

20. M.B. Skvortsov, A.D. Dzyublo, O.V. Grushevskaya, M.N. Kravchenko, I.V. Uvarova, Laptev, Sea shelf: qualitative and quantitative assessment of hydrocarbon potential. Geologiya nefti i gaza, 1:5-19 (2020).

21. I.D. Polyakova, G.Ch. Borukaev, Structure and petroleum potential of the Laptev Sea region. Lithology and Mineral Resources, 52: 278-294 (2017).

22. K. Trabelsi, J. Espitalié, A.-Y. Huc, Characterization of Extra Heavy Oils and Tar Deposits by modified Pyrolysis Methods. Proceedings of the "Heavy Oil Technologies in a Wider Europe” Thermie EC Symposium, Berlin: 30-40 (1994).

23. A.A. Hare, Z.Z.A. Kuzyk, R.W. Macdonald, H. Sanei, D. Barber, G.A. Stern, F. Wang Characterization of sedimentary organic matter in recent marine sediments from Hudson Bay, Canada, by Rock-Eval pyrolysis. Organic Geochemistry, 68: 52-60. (2014).

24. F. Behar, B. Beaumont, B. De, H.L. Penteado, Rock-Eval 6 technology: performances and developments. Oil \& Gas Science and Technology, Revue IFP 56: 111-134 (2001). 
25. V.N. Melenevskii, G.A. Leonova, A.S. Konyshev, The organic matter of the recent sediments of lake Beloe. Geology and Geophysics, 52(6): 751-762 (2011).

26. V.N. Melenevskii, S.V. Saraev, E.A. Kostyreva, V.A. Kashirtsev, Diagenetic transformation of organic matter of the Holocene Black sea sediments according to pyrolysis data. Geology and Geophysics, 58(2): 273-289 (2017).

27. E.V. Gershelis, R.S. Kashapov, A.S. Ruban, I.A. Oberemok, A.A. Leonov, D.V. Chernykh, O.V. Dudarev, I.P. Semiletov, Identifying sources of organic carbon in surface sediments of Laptev sea shelf using a Rock-Eval approach. Bulletin of the Tomsk Polytechnic University. Geo Assets Engineering, 331(8): 189-198 (2020).

28. J.R. Disnar, B. Guillet, D. Keravis, C. Di-Giovanni, D. Sebag, Soil organic matter (SOM) characterization by Rock-Eval pyrolysis: scope and limitations. Organic Geochemistry 34: 327-343 (2003).

29. F.P. Shepard Nomenclature based on sand-silt-clay ratios. Journal of Sedimentary Petrology 24(3): 151-158 (1954).

30. E. Gershelis, I. Goncharov, O. Dudarev, A. Ruban, I. Semiletov, Characterization of organic matter in bottom sediments of Ivashkina Lagoon, Laptev Sea. E3S Web of Conferences, 98: 06006 (2019). 